DOI https://doi.org/10.18551/rjoas.2017-02.29

\title{
BUSINESS ANALYSIS OF SMOKED FISH TO INCREASE SMALL SCALE FISHERMEN'S HOUSEHOLD INCOME
}

\author{
Intyas Candra Adi*, Koestiono Djoko
}

Social Economic Program, Faculty of Agriculture, University of Brawijaya, Indonesia

\author{
Agus Tjahjono \\ Social Economic Program, Faculty of Marine and Fisheries, University of Brawijaya, Indonesia \\ *E-mail: candra.intyas@gmail.com
}

\begin{abstract}
As much as $62.63 \%$ of Poor citizen in Indonesia comes from Rural and coastal communities. Development policy in fisheries sector only take sides for large scale fishermen only thus leading to over exploitation of fishery resources. In order increase the income, small - scale fishermen's household do some livelihood alternative amongst them is smoked fish business. The purpose of this research is to analyze the value added from fresh fish to smoked fish which done by small - scale fishermen's household who also members of processing group and the marketer (poklashar). Added value analysis is used to determine how much added value for a commodity because of its functional input which is done to the comodity. The research location determined in purposive with consideration that Tasikmadu village has Nusantara fishery port with the big amount of used summed from the small scale fishermen expecially hand lines fishermen. The sampling method is multistage cluster sampling. The data analysis is used hayami method of added value. The research result shows that small scale fishermen household who become members of poklashar have bigger value added than (Rp. 14.672 / kg with added value ratio of $36.28 \%$ ) small scale fishermen households who are not members (Rp. $9.971 / \mathrm{kg}$ with added value ratio $28.86 \%$ ).
\end{abstract}

\section{KEY WORDS}

Fisheries institution (Poklashar), added value, smoked fish.

The coastal communities which are consist of fishermen, fish farmers, processors and traders of marine products, as well as other community socio-economic life depends on marine resources which is a segment of the nation in general, is still relatively poor. According to the data KKP (2014), 62.63\% of the poor in Indonesia come from rural and coastal communities.

Fisheries development efforts have created sizeable foreign exchange, but only some fishermen get improvements revenue, while most fishermen are still in a state of poverty. Various programs for the development of fisheries is generally not profitable for small scale fishermen and only in favor of large scale fishermen also leading to over exploitation of fishery resources. The Modernization of fishing equipment can only be enjoyed by large scale fisherman who has strong experienced capital and access to power holders whereas government policies that focus on increasing productivity often ignore the interests of small fishermen. This makes the domestic life of small-scale fishermen become more marginalized and in poverty (Tain, 2011).

According to Allison and Horemans (2006), the vulnerability of the livelihoods associated with the risk contained in the livelihood systems and capabilities to adapt to the occurring impacts. Low levels of education, lack of skills and assets, expecially land causing small scale fishermen difficulties in adapting.

With the conditions concerned by small-scale fishermen, one of the efforts to increase the income of smallscale fishermen household is to look for a livelihood alternative by cultivating traditionally caught fishes in accordance with the capital they have. 
Traditionally processed fish, or "traditional cured" is a product that is processed in a simple and commonly performed on an household industrial scale because the tools and the processing methods are traditionally so it does not require a large capital. Type of processing methode that include in the traditional processed products are boiled fish, dried fish or dried salted fish, smoked fish, and fermented products, namely soy sauce, peda, shrimp paste, and else. Smoked fish in Indonesia is one of the traditional processing methods which are good enough to utilyze fisheries where usually household small-scale fishermen chose this method.

Simple processing method of the to the fish can create added value which is expected to increase the income of fishermen's household. According to Purba (1986), by analyzing the added value the amount of labour and processor share can be known. Analysis of the added value is also useful to know how many additional value contained in one unit of output produced. According Jamaliah (2015), the private investment has a significant positive effect on the production of value added, employment and labor productivity.

Empowerment of coastal communities by strengthening economic institutions are built from the local community of fishermen is also very necessary as a solution to the structural poverty. According Kosamu (2014), the power of social capital that comes from the local community greatly affect the sustainability of small-scale fisheries in the resources scale. Government involvement will not work if the social capital of the local community is weak which is led to discontinuation in all of its aspects. Therefore the Government's key role in small-scale fisheries, especially in developing countries is by supporting the local institutions.

Development of the National Community Empowerment (PNPM Mandiri) is one of the Government's program associated with the institutional development of the local economy with programs such as the activities of Business Development Mina Rural (PUMP) with one of its role to fund the productive economy in instituion (Group Processors and Marketers Poklashar) to the initial establishment of fishing 'Koperasi' managed by members (KKP, 2011).

From the background stated, it can be formulated that the object of the the research is to analyze the added value of the small-scale fishermen's household by processing frsh fish into smoked fish to the members and non-members of Poklashar.

\section{METHODS OF RESEARCH}

The method used in this research is a case study method. According to Nazir (2003), a case study is a study on the status of research subjects related to a specific phase of the whole personality, the study subjects may be individuals, groups, institutions and communities. The purpose of case studies is to provide a detailed overview of the background, characteristics and distinctive character of the case or the status of the individual will then be a matter of a general nature.

The sampling research method used is multi-stage clusters due to the inavalaibality of the sampling frame or too much of it so it took a long time and a large cost in the formulation. The methods clusters classify the unit - the unit of analysis in the population into clusters groups called clusters, which is a unit - a unit where samples will be taken. The number of the group taken must as a random sample then to all of the elements of the research in this cluster are studied. Sampling is taken on the certain stage. So one population can be divided - for the first level cluster, then on the first level cluster is divided into clusters - second level clusters and so on (Singarimbun, 1987).

In the fisrt stage of the research, the district that has many small fishermen vessles with engine power of at least $6 \mathrm{PK}$ has to be selected and Trenggalek District is chosen because the number of fisherman is large enough which is 9.656 people. The second stage is to choose subdistricts with fisherman conditions that can represent the diversity of fisherman conditions in the district level, the Watulimo Subdistrict is chosen with the highest number of fishermen which is 6.897 people that composed of 12 villages. The third stage is choosing an area that has the highest number of fisheries institution (poklashar) which is Tasikmadu village that has 10 Poklashar. Furthermore the households which has a small 
fishing vessels (the outboard motor with engine power $12 \mathrm{PK}$ and use hand lines) are to be selected.

It is obtained from the surveys small scale fishermen household who also process the catch into smoked fish are eight (8) respondents so that households who only fishing found eight (8) rosponended. The total sample is sixteen (16) respondents

The methods of data analysis used is a quantitative approach that analyzes the valueadded Hayami method. Value added is the increase in the value that occurs because the commodity get processed, transported and storaged in the production process with using / provision of functional input (Hayami et al, 1987).

Analysis of the value-added using Hayami method aims to determine productivity, the value of output, value added, profits, remuneration for labor and processing advantages which can be seen in Table 1 below.

Table 1 - Added Value Analysis Formula

\begin{tabular}{|c|c|}
\hline DESCRIPTION & VALUES \\
\hline \multicolumn{2}{|l|}{ OUTPUT, INPUT, PRICE } \\
\hline 1. Output (kg/year) & a \\
\hline 2. Raw material input (kg/year) & $\mathrm{b}$ \\
\hline 3. Workers/labours (HOK/year) & c \\
\hline 4. Convertion Factor (1/2) & $d=a / b$ \\
\hline 5. Workers Cooefficients $(3 / 2)$ & $e=c / b$ \\
\hline 6. Product Price (Rp/kg) & $f$ \\
\hline 7. Wage rate (Rp/HOK) & $g$ \\
\hline \multicolumn{2}{|l|}{ INCOME AND PROFIT (Rp/kg of raw material ) } \\
\hline 8. Raw material input & $\mathrm{h}$ \\
\hline 9. Other current input & $\mathrm{i}$ \\
\hline 10. Product $(4 \times 6)$ & $j=d \times f$ \\
\hline 11. a. Value Added $(10-9-8)$ & $k=j-h-i$ \\
\hline b. Value Added ratio $((11 \mathrm{a} / 10) \times 100 \%)$ & $\%=(k / j) \times 100 \%$ \\
\hline 12. a Labour income $(5 \times 7)$ & $\mathrm{m}=\mathrm{e} \times \mathrm{g}$ \\
\hline b Labour's share $((12 a / 11 a) \times 100 \%)$ & $\mathrm{n} \%=(\mathrm{m} / \mathrm{k}) \times 100 \%$ \\
\hline 13. a Processor Profit $(11 a-12 a)$ & $\mathrm{o}=\mathrm{k}-\mathrm{m}$ \\
\hline b Profit rate $((13 a / 11 a) \times 100 \%)$ & $\mathrm{p} \%=(\mathrm{o} / \mathrm{k}) \times 100 \%$ \\
\hline \multicolumn{2}{|l|}{ RETRIBUTION OF PRODUCTION FACTOR } \\
\hline 14 Margin $(10-8)(\mathrm{Rp} / \mathrm{Kg})$ & $q=j-h$ \\
\hline a. Labour income $((12 \mathrm{a} / 14) \times 100 \%)$ & $r \%=(m / q) \times 100 \%$ \\
\hline b. other current input $((9 / 14) \times 100 \%)$ & $s \%=(i / q) \times 100 \%$ \\
\hline c. Processors Profit $((13 a / 14 \times 100 \%)$ & $\mathrm{t} \%=(\mathrm{o} / \mathrm{q}) \times 100 \%$ \\
\hline
\end{tabular}

Source: Hayami, et al, 1987.

\section{RESULTS AND DISCUSSION}

Small - scale fishermen' household conduct some livelihood alternative to meet their needs as fluctuative fish caught and seasonal conditions that can not be predicted.

Traditional processing method is chosen by small-scale fishermen household for its number of fish caught per fisherman is relatively small, the type and size of the fish are diverse and do not require substantial capital investment. Simple processing method for fresh fish can create added value which is then expected to increase the income of fishermen by which is that smoked fish processing.

From the results, value-added business of smoked fish either as a member Poklashar or not members, can be seen in Table 2.

From the calculation of the average of the added value in Table 3, it can be concluded that:

Production result / output for one year in the business of processed smoked fish on average fisherman group 1 with average of $4,320 \mathrm{~kg} /$ year with the use of raw materials amounted to $4,740 \mathrm{~kg}$ / year while the average fisherman group 2 - average of $4968 \mathrm{~kg}$ / year with the use of raw materials amounted to $5,490 \mathrm{~kg} /$ year. The result of fishermen's group 1 
is fewer than group 2 because the frequency of smoked fish activities fishermen's group 1 was low (only weekends and holidays), while group 2 was almost every day.

Output price for fishermen group 1 is valued at Rp. $45471,-/ \mathrm{kg}$ compared to the price of the output of fishermen's group 2 is valued at Rp. $36532,-/ \mathrm{kg}$. This is because as a member of Poklashar, fisherman group 1 get location facilities at tourist spots which is Prigi beach while fisherman group 2 usually sells in traditional market or selling around to neighbors.

Table 2 - Added Value Analysis of Smoked Fish by Small - scale fishermen's household Rumah Tangga (Poklashar Members) in Tasikmadu Village, Watulimo Subdistict for One Year

\begin{tabular}{lll}
\hline DESCRIPTION & 1 & 2 \\
\hline OUTPUT, INPUT, PRICE & 4.320 & 4.968 \\
1. Output (kg/year) & 4.740 & 5.490 \\
2. Raw material input (kg/year) & 1.632 & 2.070 \\
3. Workers/labours (HOK/year) & 0,89 & 0,89 \\
4. Convertion Factor (1/2) & 0,43 & 0,49 \\
5. Workers Cooefficients (3/2) & 45.471 & 36.523 \\
6. Product Price (Rp/kg) & 7.208 & 6.256 \\
7. Wage rate (Rp/HOK) & & 18.500 \\
INCOME AND PROFIT (Rp/kg raw material) & 21.625 & 3.529 \\
8. Raw material input price & 4.103 & 32.000 \\
9. Other current input & 40.400 & 9.971 \\
10. Product (4 6 ) & 14.672 & 28,86 \\
11. a. Value Added (10 - 9-8) & 36,28 & 3.185 \\
b. Value Added ratio ((11a/10) x 100\%) & 2.968 & 33,81 \\
12. a Labour income (5 x 7) & 19,58 & 6.786 \\
b Labour's share ((12a/11a) x 100\%) & 11.704 & 19,42 \\
13. a Processor Profit (11a - 12a) & 29,00 & 13.500 \\
b Profit rate ((13a/11a) x 100\%) & & 23,86 \\
RETRIBUTION OF PRODUCTION FACTOR & 18.775 & 28,78 \\
14 Margin (10 - 8) (Rp/Kg) & 15,32 & 47,86 \\
a. Labour income ((12a/14) x 100\%) & 21,93 & 62,74 \\
b. other current input ((9/14) x 100\%) & & \\
c. Processors Profit ((13a/14 x 100\%) & & \\
\hline
\end{tabular}

*Note: Small - scale fishermen's household (1) Poklashar member's and (2) Non-member's.

The labor in the processing of smoked fish for one year in fishermen group 1 average of 1,632 person-days / year while the average fisherman group 2 - average of 2,070 persondays / year. Number of HOK / year in fishermen's group 1 less than in group 2 because fishermen group 1 do smoked fish activity only during holiday and weekend while fsherman group 2 almost every day.

The amount of the conversion factor in fishermen's group 1 and group 2 is 0.89 which means that $1 \mathrm{~kg}$ of raw material is needed to produce $0.89 \mathrm{~kg}$ of smoked fish.

The coefficient of labor to process fresh fish in to smoked fish on the fisherman group 1 is 0.43 person-days or 3.4 hours which means that $1 \mathrm{~kg}$ of raw material input requires as much labor as $0.43 \mathrm{HOK}$ or 3.4 hours while in group 2 is $0.67 \mathrm{HOK}$ or 6.7 hours which means $1 \mathrm{~kg}$ of raw material input requires as much labor as 0.49 HOK or 6.7 hours. These long working hours included waiting for a buyer. The coefficient of labor in the fisherman group 1 is fewer than fisherman group 2 due to the division of labor for fishermen group 1 (the number of workers 2-3 person), while the fishermen's group 2 usually work by themselves (the number of workers 1-2 person).

The average of wage rate / day / person-days for one production processing on fishermen group $1 \mathrm{Rp} 7208$, - day / HOK while the fishermen group 2 Rp 6256, - day / HOK. Average of wage rate wage rate / day / HOK of fishermen group 1 is higher than the fishermen group 2 because the fisherman group 1 profit is higher.

The input price of raw material used is fresh fish in which the fishermen group 1 the average price of Rp. $21625,-/ \mathrm{kg}$ whereas in the fishermen group 2 of Rp. 18.500, -/ kg. The averages of raw material input fisherman groups 1 is greater than the fishermen group 2 . This is because generally the buyer of fishermen group 1 is tourists who visit Prigi beach so 
the species of fish sold are more diverse and has a high economic value and preferred by consumers such as snapper red, kweh rombeh, squid / cuttlefish, mackerel and pomfret while fishing groups 2 usually sell swordfish, yellowfin tuna and salmon..

Other current input in the fishermen group 1 is $\mathrm{Rp} 4.103,-/ \mathrm{kg}$ of raw materials compared to the fishermen group 2 is $\mathrm{Rp} 3,529,-/ \mathrm{kg}$ of raw material. This is because some of the equipment used by fishermen group 1 is more modern, transportation costs bigger and the packaging is more actractive.

The added value of processing fresh fish into smoked fish on fishermen group 1 is Rp 14672 , - / kg with added value ratio of $36.28 \%$, while in the fishermen group 2 the added value of $\mathrm{Rp} .9971,-/ \mathrm{kg}$ with added value ratio $28.86 \%$.

The labor income provided from each kilogram of fresh fish raw material processed into smoked fish on the fisherman group 1 is Rp. 2.968, - the labour's share percentage is $19.58 \%$, while in the fishermen group 2, the labor income is Rp. 3.185 with a labour's share percentage is $33.81 \%$.

The profit amount obtained from the processing of fresh fish on a fishermen group 1 is Rp.11 704, - / kg with profit rate of $29.00 \%$ of the value of the product / output, while in fishermen group 2 the amount of profit is $\mathrm{Rp} .6786,-$ / $\mathrm{kg}$ with profit rate of $19.42 \%$.

In the fishermen group 1 , each $1 \mathrm{~kg}$ of fish processed into smoked fish obtained margin of Rp 19,000, - is distributed to each factor which is labor income about $24.56 \%$, other current input is $23.27 \%$ and processor profit is $52,16 \%$ whereas in the fisherman group 2 , each $\mathrm{kg}$ of fish processed into smoked fish obtained margin of Rp 13.500 , - is distributed to each factor which are labor income is $23,86 \%$, other current input is $28,78 \%$ and processor profit is $47,36 \%$.

\section{CONCLUSION}

The average value added which obtained by small - scale fishermen's household who are the members poklashar (Rp. $21625,-/ \mathrm{kg}$ with added value ratio of 36.28\%) is bigger than small - scale fishermen's household who are non member (Rp. 18.500, - / kg with added value ratio of $28.86 \%$ ).

\section{REFERENCES}

1. Allison, E.H. and Horemans, B. (2006). Putting The Principles Of The Sustainable Livelihoods Approach Into Fisheries Development Policy And Practice. Marine Policy 30: 757-766.

2. Hayami, Y., Kawagoe, T., Morooka, Y., and Siregar, M. (1987). Agricultural Marketing and Processing in Upland Java A Perspective From A Sunda Village. CPGRT Centre, Bogor.

3. Kosamu, I.B.M. (2015). Conditions For Sustainability Of Small-Scale Fisheries In Developing Countries. Fisheries Research 161: 365-373.

4. Jamaliah. (2015). The Effect of Investment to Value Added Production, Employment Absorption, Productivity, And Employees Economic Welfare in Manucaturing Industry Secato In West Kalimantan Province. Procedia - Social and Behavioral Sciences 219: 387-393.

5. KKP (Kementrian Kelautan dan Perikanan). (2014). Kelautan dan Perikanan Dalam Angka 2014. Pusat Data Statistik dan Informasi, Jakarta.

6. Peraturan Menteri Kelautan Dan Perikanan Republik Indonesia Nomor Per.41/Men/2011. Pusat Data Statistik dan Informasi, Jakarta.

7. Nazir, Moh Ph.D. (2003). Metode Penelitian. PT Ghalia Indonesia, Jakarta.

8. Purba, R. (1986). Manajemen Manunggal Bagi Wiraswasta. Pustaka Dian, Jakarta.

9. Singarimbun, M. and Effendi, S. (1987). Metode Penelitian Survei. Penerbit LP3ES, Jakarta.

10. Tain, A. (2011). Penyebab Kemiskinan Rumah Tangga Nelayan Di Wilayah Tangkap Lebih Jawa Timur. Jurnal Humanity 7(1), http://ejournal. umm.ac.id/index.php/article/view 